\title{
A Watershed Conservation Success Story in Nepal: Land Use Changes Over 30 Years
}

\author{
Bill and Jeanie Fleming ${ }^{1}$
}

University of New Mexico

\begin{abstract}
In the middle hill region of west central Nepal in 1977, a quarter of a $113 \mathrm{~km} 2$ watershed experienced erosion rates exceeding $30 \mathrm{Mt} / \mathrm{ha} / \mathrm{yr}$ due to high rainfall intensities, unstable soils, steep slopes and severe overgrazing. This increasing land degradation coupled with indiscriminate forest harvesting threatened the survival of forests and viable pasture lands. However, an innovative national government policy of handing over forest management to local people was put in place over the next three decades, resulting in conversion of nearly all the eroded grazing and shrub land to managed pasture and forest, a five-fold increase in grass and fodder and a near-doubling of forest productivity. While $43 \%$ of project costs were spent on user group formation and vegetative restoration, this provided most of the social, environmental and economic benefits.

Structural measures, such as check dams and channel control were the most costly (57\%) but provided the least livelihood and economic benefits. Interviews in 2006 with farmers and forest users in the watershed added complementary anecdotal evidence that a community's environmental education, coupled with increased control over their local pasture and forest, provided valuable incentives for success in sustainable resource management.
\end{abstract}

\section{Introduction}

The opportunity to return to an international project begun 30 years ago does not happen often, and it was with excitement tempered with cautious optimism that we returned to Nepal for this purpose in 2006 during Bill's sabbatical leave from the University of New Mexico. The Food and Agriculture Organization of the United Nations (FAO) encouraged us to revisit the Phewa Tal watershed (Kaski district) where as part of Bill's

${ }^{1}$ Bill Fleming is an Associate Professor in the Community and Regional Planning program, School of Architecture and Planning, University of New Mexico, where he teaches environmental planning and watershed management. Jeanie Puleston Fleming is a freelance writer, editor and photographer. 
work on an FAO-assisted project in 1977-78 he had assessed water quality, land use and hillside stability. I often joined him in the field to photograph watershed conditions.

The watershed, $140 \mathrm{~km}$ west of Kathmandu and adjacent to the town of Pokhara, comprises $113 \mathrm{~km} 2$ and drains into one of the country's most prominent lakes, Phewa Tal. Topography is steep; slopes average 40 percent, and elevations range from $850 \mathrm{~m}$ at the lake to $2,500 \mathrm{~m}$ at Panchase Peak. The lake, the town and treks into the nearby Annapurna range make the area a popular tourist destination. In 1977, forest land, including that classified as shrub, comprised 35 percent of the watershed, all owned and controlled by the national government of Nepal (Fleming 1983). While terrace land was beautifully maintained, overgrazed land was eroding, and forests were being stripped of even small trees for firewood and fodder. When we left in late 1978, the future of the forest and pasture lands was in doubt. The project final report contained pessimistic long-term predictions based on land and natural resources use practices. Without changes in resource management, uncontrolled grazing and indiscriminate firewood collection with subsequent erosion were likely to devastate hillside farmland, pasture and forest cover.

Upon our arrival in Kathmandu in 2006 we contacted forestry officials and other experts and sought out government and NGO reports of work done in the intervening years. In Pokhara we met local foresters and other resource managers and walked the watershed to talk with residents and see the land again, concentrating on the northern side of the watershed which had been in the worst condition in 1977. From hilltops there were views into the southern forest where a Maoist conflict with the army made our entry impossible.

The reports, scientists and residents told the story of a practical, creative forest policy that, with advice and ongoing evaluation by district forest officers, progressively turned over management responsibilities to groups of local people, Community Forest User Groups (CFUGs) who live adjacent to the forested areas. The shift in management included an end to open grazing and a program to improve livestock (FAO 1987). By 2004, CFUGs had come to manage 25 percent of the Nepal's forest land (Kanel 2004). In 2009, one-third of Nepal's population was actively involved in managing one-fourth of Nepal's forest lands (Ojha et al 2009). In the Phewa Tal watershed the percentage was much higher, exceeding $60 \%$. Our observations, reinforced by aerial photographs and satellite imagery, were that forest and grazing land had not only recovered but improved markedly under the community forest policy of delegating forest management to its primary beneficiaries. 


\section{Land Use Situation in 1977-78}

The devolution of control over the forests in Nepal has followed a zigzag path, evidenced by a brief history of forest policy. As early as the 1600s a royal edict of King Ram Shah recognized the importance of forests in the protection of the environment:

"Maintain trees around water springs. In the absence of trees, water will not last all through the year and the spring will run dry. If forests are cleared on a massive scale, there will be many landslides. Landslides will bring floods that could wash away even khet (level terraces). Thus five rupees fine to whosoever cuts trees around water sources." (Bhatterai and Khanel 2005). A tradition of communal use of local forests developed over time.

The Rana Period (1846-1950) was one of active forest clearing for agriculture, alienation of communal rights and concentration of forest rights in the hands of the ruling class, along with increasing timber sales (Bhatterai and Khanel 2005). With the overthrow of the Ranas in 1950 and the establishment of new government institutions, forests were considered a part of national wealth and forest protections a duty of the state with a top-down model of governance. The Forest Act of 1961 along with other laws reinforced the government's ownership rights and made many traditional resource uses illegal (Bhatterai and Khanel 2005). National ownership was not combined with management, and as the policy of protections from deforestation was unenforceable, disruption of community-led governance resulted in accelerated use by villagers who were not given incentives for long term sustainable use (Fleming 1983). This policy was inappropriate for fuel wood and fodder management because land tenure tradition regarded forests as art of the resources of particular villages even though these lands were not registered for legal ownership.

With the enactment of the National Forestry Plan of 1976 and the Panchayat Forest Law of 1978, individual panchayats (village councils) could establish CFUGs and control up to 125 ha of shrubland for reforestation and could manage up to 250 ha of government forest on a sustained yield basis, receiving $40 \%$ of the net income from forest products (Fleming 1983). By 1978, these first steps toward devolution of forest management had yet to significantly affect conditions in the watershed.

Land use analysis of the watershed, determined from aerial photographs and field observation in 1977, showed nearly half the land in terrace, $28 \%$ in unmanaged forest, $11 \%$ in open grazing, $7 \%$ in degraded 
shrub and at least $1 \%$ in gullies or landslides. Shrub and forest land was also grazed and/or used for fodder. About $10 \%$ of the basin is flat to rolling (0-10\% slope), 60\% has slopes between 20 and 60\% (averaging $40 \%)$ and $15 \%$ is very steep (60\%-100\% slope). The rainfall pattern is monsoonal, with $85 \%$ of the annual total of $5400 \mathrm{~mm}$ falling between June and September, often in brief, intense and erosive storms (Fleming 1983).

Terraces in the Phewa Tal were well constructed, and runoff from arable land under terraces was slight, causing no significant erosion damage. Erosion from forest land at $8 \mathrm{Mt}$ ha/yr was five to ten times greater than that of natural forests due to grazing activity and intensity of rainfall. The estimated soil loss from shrub land was even higher at $15 \mathrm{Mt}$ ha/yr. The most critical category was grazing land. Although comprising only $11 \%$ of the area, it could be credited with as much as $29 \%$ of the soil loss (Fleming 1983). Demonstration erosion plots on open grazing land and on pasture protected by a fence showed protected pasture lost 9.2 $\mathrm{Mt} / \mathrm{ha} /$ year, while open grazed land lost $34.7 \mathrm{Mt} / \mathrm{ha} /$ year. Without a watershed conservation program and population growth exceeding 2\%/year, forest land could have disappeared by 1996 (Fleming 1983).

\section{Measures Implemented Since 1978}

Recommendations for a watershed management program to address soil erosion, land degradation an economic sustainability grew from experience in the Phewa Tal in 1977-78 (Fleming 1978). Measures included protection of existing forest and management on a sustainedyield basis, conversion of open grazing land to protected pasture, reforestation on selected sites, check dams in gullies, river control structures, training of local individuals as conservation assistants, and a balance between national and local objectives.

Erosion plots and soil loss equations were used to measure and estimate erosion rates as an indicator of watershed health and to identify land use categories as priorities for watershed restoration (Fleming 1983). Maintaining the nutrient pool in the soil is the key to long-term agricultural productivity, and when soil is lost the nutrients are also depleted (Brown et al 1999).

Soil loss rates from erosion plots on eroded grazing land and protected pasture were recorded.

Production rates for fuelwood and fodder from managed and unmanaged forest and grazing land were measured during the second year of the project by professional foresters and range managers (Fleming 1983). 
Estimating increases in land productivity and resulting livelihood benefits with the watershed management program was the basis of an economic analysis. Monetary values were assigned to land use categories of varying productivity (open grazing land, protected pasture, unmanaged forest, and managed community forest). The analysis then compared the value of the land without the program to its value with the proposed conservation plan. The differences between the two values are assumed to approximate the monetary benefits of watershed management interventions. Benefits that are difficult to value, such as domestic water supplies and their associated health benefits, and have not been included. The calculations are based on the values in Tables 1, 2 and 3 .

Table 1. Production of Wood and Fodder (per hectare per year)

\begin{tabular}{|l|l|l|l|l|l|}
\hline $\begin{array}{l}\text { LAND } \\
\text { USE }\end{array}$ & $\begin{array}{l}\text { Grazing } \\
\text { land }\end{array}$ & $\begin{array}{l}\text { Pasture } \\
\text { land }\end{array}$ & $\begin{array}{l}\text { Shrub } \\
\text { land }\end{array}$ & $\begin{array}{l}\text { Unmanaged } \\
\text { forest }\end{array}$ & $\begin{array}{l}\text { Managed } \\
\text { forest }\end{array}$ \\
\hline $\begin{array}{l}\text { Grass } \\
\text { (kg) }\end{array}$ & 1200 & 6000 & 500 & -- & -- \\
\hline $\begin{array}{l}\text { Tree } \\
\text { foliage } \\
\text { (kg) }\end{array}$ & -- & -- & 1500 & 3000 & 5000 \\
\hline $\begin{array}{l}\text { Wood } \\
(\mathrm{m} 3)\end{array}$ & -- & -- & 4 & 12 & 20 \\
\hline
\end{tabular}

Table 2. Production and Value of Fertilizer from Grass and Fodder Foliage

\begin{tabular}{|l|l|l|}
\hline Fertilizer & $\begin{array}{l}\text { Production/animal/year } \\
(\mathrm{kg})\end{array}$ & Value $(\mathrm{Rs} / \mathrm{kg})$ \\
\hline Nitrogen & 15 & 6 \\
\hline Phosphorus & 2 & 18 \\
\hline
\end{tabular}

Table 3. Production and Value of Milk from Grass and Fodder Foliage

\begin{tabular}{|l|l|l|}
\hline Milk & $\begin{array}{l}\text { Production/1000 kg feed } \\
\text { (liters) }\end{array}$ & Value (Rs/liter) \\
\hline Grass feed & 60 & 1 \\
\hline Foliage feed & 120 & 1 \\
\hline
\end{tabular}

Production of grass from protected pasture is approximately five times greater than from open grazing land, resulting in a fertilizer value of Rs 55 per ha and a milk value of Rs 360 per ha (Fleming 1983). Fodder production from the enclosure yielded $6,000 \mathrm{~kg} / \mathrm{ha} /$ year of green fodder, compared with $1,200 \mathrm{~kg} / \mathrm{ha} / \mathrm{year}$ from open grazing land in the watershed.

Fuelwood is produced on both shrublands and forest lands. Two methods were used to estimate fuelwood values (Fleming 1983). First is a direct market value approach based on the 1978 fuelwood price in Pokhara (Rs 13 for a $37 \mathrm{~kg}$ bundle). Assuming an average wood density of 500 
$\mathrm{kg} / \mathrm{m} 3$, fuelwood would be worth Rs $174 / \mathrm{m} 3(500 \mathrm{~kg} / \mathrm{m} 3 \times \mathrm{Rs} 13 / 37 \mathrm{~kg}=$ 174). A seond method was an opportunity cost approach based on the time families spend carrying fuelwood from the forest (Fleming 1983). This method assumes that: a) $30 \mathrm{~kg}$ of fuelwood are collected daily by each family; b) each family spends an average of 132 worker-days/year collecting fuelwood; c) $30 \mathrm{~kg}$ of fuelwood is the energy equivalent of 20 $\mathrm{kg}$ of dry wood with a volume of $0.04 \mathrm{~m} 3$. Therefore, each family gathers $5.3 \mathrm{~m} 3$ of fuelwood annually and at a daily gathering wage of Rs 5 (the opportunity cost of labor based on other employment), the value would be $125 \mathrm{Rs} / \mathrm{m} 3$ (5 Rs/day x 132 days/year/ $5.3 \mathrm{~m} 3 /$ year). The average of the results from the two methods is Rs $150 / \mathrm{m} 3$.

Table 4. Estimated Land Values in the Phewa Tal Watershed (Rs/ha/yr)

\begin{tabular}{|l|l|l|l|l|l|l|}
\hline & Grass & Grass & $\begin{array}{l}\text { Fodder } \\
\text { Leaves }\end{array}$ & $\begin{array}{l}\text { Fodder } \\
\text { Leaves }\end{array}$ & & \\
\hline Land Use & Fertilizer & Milk & Fertilizer & Milk & Fuelwood & Total \\
\hline Grazing & 11 & 72 & & & & 83 \\
\hline Pasture & 55 & 360 & & & & 415 \\
\hline Shrub & 5 & 30 & 27 & 180 & 384 & 626 \\
\hline $\begin{array}{l}\text { Forest } \\
\text { (unmanaged) }\end{array}$ & & & 53 & 360 & 1152 & 1565 \\
\hline $\begin{array}{l}\text { Forest } \\
\text { (managed, } \\
\text { after 6 years) }\end{array}$ & & 89 & 600 & 1900 & 2609 \\
\hline $\begin{array}{l}\text { Plantation } \\
\text { forest (5-10 } \\
\text { years) }\end{array}$ & & 22 & 144 & 480 & 646 \\
\hline $\begin{array}{l}\text { Plantation } \\
\text { forest (after } \\
\text { 10 years) }\end{array}$ & & 44 & 288 & 960 & 1292 \\
\hline
\end{tabular}

Other potential benefits of the proposed management plan were not calculated, such as hydroelectric power, tourism and fisheries.

After the panchayat system proved ineffective in monitoring the protection of the forests and in ensuring equitable distribution of forest products, a new system was initiated by the 1993 Forest Act that recognized CFUGs as independent entities, separate from local government, allowing their forests to overlap political boundaries of villages and districts (Bhatterai and Khanel 2005). Users desiring to manage a forested area as a group must file an application including a constitution identifying member and a work plan. Components of the work plan include: a map of the forest area, a description of the condition and 
type of forest, objectives for sustainable management, proposed conservation methods, sale and distribution of forest products, wildlife preservation, and special programs for women and underprivileged classes. CFUGs are structured to promote cooperation in protecting the common forest resources.

At a national workshop in 2004, major stakeholders in community forestry gathered in Kathmandu to evaluate the program's past and guide its future. Kanel (2004) addressed the challenges of coordinating collective action in the area of community forest management, from resistance to change to formulation and enforcement of rules. Communication and the social relationships of trust, reciprocity and commitment to group decisions facilitate the process. "Social or even forestry reform is not linear, but an iterative and 'muddling through' process. There is an unanimous and converging view that community forestry has brought a fundamental shift in forests management paradigm. The shift in mindset is that institutional innovation or reform would precede technical innovation. That is the reason we think that governance reform is a prerequisite for sustainable forest management and livelihood promotion. Intervention and innovation is a slow process since all the stakeholders have to agree on innovations and reforms.... There is a critical mass of committed government staff in the forestry sector, members of civil society and forest users who agree for the need of such reforms. Some may resist change, but frequent coaching may be necessary to change their mind-sets." (Kanel, 2004)

Interviews in the Phewa Tal watershed provide a snapshot of how the participatory program functions while still allowing room for improvement:

Women and disadvantaged minorities are encouraged to participate in CFUGs, but roles change slowly. The president of one Phewa Tal CFUG, said three women are members of the core committee, but they never speak and none are officers. Still, results have been good; the group's forest of 61 hectares is in much better condition and produces far more than in his father's time.

An example of rules bent to tolerate the very poor is the situation of a low caste woman washing clothes at a village water spigot while her young child sits in the dirt nearby. She moved to the community from higher ground 10 years ago, but has not joined the CFUG because she claims the admission fee was too high. Her solution, she says with a laugh, is either to buy fuelwood a few pieces at a time or wait until the forest watcher goes off duty so she can sneak into the forest for downed wood. So far no one has stopped her, though they know how she survives. 
When the forest cannot provide enough for all, the burden is spread out among families. One mother and farmer collects wood on designated days along with the 165 households in her CFUG near Phewa Lake. "It isn't enough. We have to buy extra wood, but we are managing, she says with a shrug.

\section{Situation in 2006: Land Use Changes in Phewa Tal Watershed}

The scattered houses that constitute the settlement of Banpali sit just below the ridge that marks the northern boundary of the Phewa Tal watershed. Word spread quickly that visitors with questions had arrived, and soon a knot of interested villagers gathered around us to examine photos of Bill's 1978 erosion plots. One man remembered them, and moments later, our group was hiking up and down the slope above the new schoolhouse. It took less than half an hour to locate remnants of the plots, mostly hidden by a diverse assemblage of vegetation. The wire fence was gone, unneeded in the current era of social fencing in which grasses and fodder are cut and carried to stall-fed animals. The former fenced area had evolved into forest, and a mat of thick grass covered the formerly denuded grazing land. The plots had done their job, providing scientific data on erosion rates, showing farmers the need for land use changes, and decades later providing a graphic indication of improved watershed health.

By 2006, 2739 ha or $24 \%$ of the watershed area had been handed over to 95 Community Forest User Groups (CFUGs), and each group had developed a plan for long term sustainable management approved by the district forest office (Kaski District Forest Office files, 2006). Previously unmanaged forest land had decreased to $12 \%$ of the watershed area. Although no comprehensive analysis comparing the quality of community forests with unmanaged forest land were available for the Phewa Tal, community forests were observed in 2006 to have a dense vegetation cover and a wide diversity of species for fuelwood, fodder and other uses.

Land use changes between 1978 and 2006 were documented with two periods of aerial photograph and satellite imagery interpretation, combined with field observations (Table 5; Fleming 1983). Terraced arable land remained constant while forest land increased from $28 \% 5036 \%$, mainly resulting from conversion from unmanaged forest and degraded shrub and grazing land to managed community forest (Table 5). Degraded grazing and shrub land, nearly $20 \%$ of the watershed in 1978 , was converted to managed pasture or community forest by 2006 . Unproductive shrub land, $7 \%$ of the watershed in 1978, was managed pasture or forest by 2006 .

Table 5. Land Use Changes from 1978 to 2006 in the Phewa Tal Watershed 
(\% of total watershed area)

\begin{tabular}{|l|l|l|l|}
\hline & $1978^{*}$ & & $2006^{* *}$ \\
\hline $\begin{array}{l}\text { Terraced arable } \\
\text { land }\end{array}$ & 46 & 46 \\
\hline Unmanaged Forest & 28 & & 12 \\
\hline Community forest & 0 & 11 & $24^{* * *}$ \\
\hline $\begin{array}{l}\text { Unrestricted } \\
\text { grazing }\end{array}$ & 7 & 1 \\
\hline Degraded shrub & 1 & 1 \\
\hline Managed pasture & 1 & 9 \\
\hline Gullies/landslides & 1 & & 1 \\
\hline Lake/urban & 6 & 6 \\
\hline
\end{tabular}

*determined from aerial photographs

**estimated from field observations, interviews and LANDSAT imagery

$* * * 2739$ ha or $24 \%$ of the watershed has been handed over to Community

Forest User Groups (Kaski District Forest Office files, 2006)

Most of the critical landscapes identified in 1978 (19\% of the watershed) had become managed pasture or community forest where social fencing restricts open grazing. Some unrestricted grazing still occurs in parts of forested landscapes, particularly in Bhadaure-Tamagi and Chapakot villages and farmers often allow grazing on terraces following harvests. The conservation and watershed management program, begun in 1974, included a variety of protection and rehabilitation measures encouraging this positive shift in land use from open grazing to protected pasture and forest. Also important was the Livestock Development Program of the Ministry of Agriculture, encouraging fewer animals but better dairy producers (FAO 1986).

Life in the area has improved since his parents' generation, a resident of the upper watershed says decisively. The land has a much better vegetation cover than previously, and while terraces occupy about the same area, farming on terraced land has intensified, and many farmers use chemical fertilizer to compensate for declining soil quality. His neighbors used to own a dozen free-grazing livestock, but now the number has decreased to two at most, all of them stall-fed and more effective milkproducers. Dung collection is more effective now that animals are stall fed, but he says that chemical fertilizer, though more expensive, works faster.

By 2006, erosion rates on the same grazing land had decreased substantially because it was not longer grazed and the vegetation cover had increased to $100 \%$. Because the erosion plots had not been maintained after the first two years of measurements, soil loss in 2006 was estimated 
with the "modified universal soil loss equation." Results from 2006 transects ranged from 1.4 to 2.7 tons/ha/year, more than ten times less soil loss than the measured values from 1978-79 and consistent with Impat's conclusions using both measured plot and estimated soil loss equation methods (Impat 1981).

After a successful search for the old erosion plots, members of the Banpale community forest user group sit on the dry winter grass nearby and describe how the surrounding land has changed in the last 30 years (Figure 3). The days of open grazing are gone, they say, as are the denuded slopes. Families used to own four or five livestock, but now the 180 households in this community forest user group each own at most two animals.

A schoolteacher-farmer pats the protective layer of vegetation growing on the formerly overgrazed and eroded hillside and points to terraces below edged with bunds that prevent soil loss. "This is much better than then," he says. "We know more."

The current problem of their CFUG is food for livestock, he says. Since open grazing is not permitted, and their 5 hectare forest is a pine plantation that does not provide fodder leaves, extra fodder must be purchased. Fodder trees that have sprouted in our forest are still too young to be useful." Another man is optimistic: "We will wait; they're growing."

\section{Economic Analysis of the Costs and Benefits}

In addition to continuous activity by Nepal's Department of Watershed Management and Soil Conservation between 1974 and 2006, three international agencies provided funding: the Food and Agriculture Organization of the United Nations FAO) from 1975 to 1984, the Finnish International Development Agency (FINNIDA) from 1985 to 1994, and the Japanese International Cooperation Agency (JICA) from 1997 to 2004 in a small part of the watershed. Costs of the services provided by all four agencies were estimated from unit costs of activities in the watershed (DSCWM 1992).

The following table shows that the actual costs of the project were more than double those projected in the 20-year plan (about Rs 54 million, compared with a projection of about Rs 26 million).

Table 6. Documented Project Costs: 1974-2006 (millions of Rs)

\begin{tabular}{|l|l|l|}
\hline Activity & Cost (Rs millions) & $\%$ of total \\
\hline $\begin{array}{l}\text { Preventive measures } \\
\text { (mainly reforestation) }\end{array}$ & 20.7 & $39 \%$ \\
\hline Rehabilitation measures & 30.9 & $57 \%$ \\
\hline
\end{tabular}


Himalayan Journal of Development and Democracy, Vol. 6, No. 1, 2011

\begin{tabular}{|l|l|l|}
\hline (mainly structural) & & \\
\hline Extension and education & 2.2 & $4 \%$ \\
\hline Total & 53.9 & \\
\hline
\end{tabular}

It is significant that nearly $60 \%$ of the costs were spent on structural measures, such as check dams and river training gabions, which did not result in significant land use changes. The underlying assumption of this analysis is that land use changes from less productive uses to more productive uses result in improved livelihood and economic gain by watershed stakeholders. While there were benefits from structural activities, in economic and livelihood terms they were small, compared to those resulting from the conversion of land use from open grazing to protected pasture and from government forest to community forest. Treating eroding gullies did not result in land use changes and often failed after the first season of monsoon rains (Fleming 1983) Economic analyses of other projects in the Middle Hills of Nepal showed that the costs of building torrent control structures, treating landslides and building embankments in riparian zones far exceeded the economic benefits valued in terms of conserved agricultural land (Achet and Fleming 2006).

Preventive vegetative measures constituted $39 \%$ of project costs, mainly conservation plantations, fruit tree planting, water source protection, and nursery establishment. Although these measures would likely result in future livelihood gains, the benefits in terms of land use changes are difficult to estimate. Only $4 \%$ of the project funds were spent on the formation of user groups, farmer training, household training, and community mobilization through conservation education and extension, while many of the benefits resulted from these activities. In terms of cause and effect, evaluating the impacts of agricultural and forestry extension projects and education (4\% of project costs) are perhaps more straightforward. A partial accounting of the substantial economic benefits accruing in improved livelihoods from conversion of open grazing land to protected pasture and from government forest to community forest is provided in this analysis.

These preventive measures and extension/education activities, valued at $43 \%$ of the project costs, resulted in substantial land use changes from grazed land to pasture and from unmanaged forest to mainly community forest (66\% of forest land). The benefits of these land use changes were livelihood enhancement, valued in terms of additional production of grass, fodder and wood, in turn resulting in increased milk, fertilizer, and forest products.

Benefits of the 32-year life of the project are calculated on the basis of the productivity of different land uses (milk, fertilizer and forest products), 
using the same economic valuation procedure and information described in the previous chapter for the projected 20-year plan. The following table shows that the benefits still exceeded the costs by a substantial amount, even with costs that were more double those predicted in the earlier plan projection.

Table 7. Benefits Over 32 Years of Management (millions of Rs discounted at $10 \%$ over 32 years)

\begin{tabular}{|l|l|}
\hline Benefits with management & 73 \\
\hline Benefits without management & 36 \\
\hline Difference & 37 \\
\hline
\end{tabular}

With benefits of Rs 37 million and costs of Rs 25 million, the ratio of benefits to costs is positive, although not as high as the 1.7 ratio projected in 1978:

Benefits of Rs 37 million / Costs of Rs 25 million $=1.5$

Many environmental services are left out of this calculation, including water quality and improved fishery, flood control, increased seasonal and spring flow, reduced lake sedimentation and hydropower benefits, ecotourism recreation and aesthetics, carbon sequestration, biodiversity and species conservation.

Seated on his front porch before classes begin, the local school principal describes the Ghata Basuli Bari and Banpale Community Forest User Group of which he is member. The group includes 95 households which meet in a general assembly twice a year. Of the 11 committee members who meet bi-monthly, three are women who often add comments.

He has seen an enormous improvement in the condition of the forest and surrounding lands near Naudanda since his childhood when the hills were denuded and overgrazed. The Department of Soil and Water Conservation planted trees, a species of alnus, he says, and the Department of Forestry handed over the land to the community forest user group. One small forest of only a hectare provides fuelwood which is collected twice a year. Everyone goes into the forest for this task, unlike before, when one woman per family used to spend all day everyday searching for wood to bring home.

Since the forest is small, families belong to a second forest user group, and still must purchase supplementary wood. The user group does not collect membership fees, but takes up a collection for a forest watcher who guards against illegal wood gathering. Grazing on communal land has ceased; families used to own four buffalo but now have two, and these are 
stall-fed. "Another change: all children go to school," he says with satisfaction.

\section{Conclusions: Getting the Most from Watershed Management}

The Phewa Tal watershed in 2006 was a tapestry of productive terraces and healthy forest, with reliable if limited supplies of water. Changes in land use were the key to the success of the project. These changes were largely brought about by a shift in government policy that allowed user groups to gain control of most of the forest $(60 \%)$ and pasture land $(90 \%)$. These user groups had an economic incentive to manage the resources sustainably. A summary of observations in the watershed includes:

1. Watershed health improved significantly from 1978 to 2006, reversing apparent trends.

2. Both benefits and costs were underestimated in the 1978 plan, but benefits still greatly exceeded costs nearly 30 years later.

3. 95 community forest user groups now control $60 \%$ of forest land and have access to productive forest resources.

4. Land use changes are key indicators of benefits because they result in valuable products (fuelwood, grass and fodder leaves), providing critical economic incentives for local user groups.

5. Nearly all formerly eroded grazing and shrub lands $(25 \%$ of the watershed) are now protected pasture or community forest. Grazing control, stall feeding and increased vegetation cover were effective in improving soil and water conservation.

6. Only $43 \%$ of project costs were spent on conservation and user group formation and vegetative restoration activities, but this provided most of the social, environmental and economic benefits. Structural measures, such as check dams and river channel training, were the most costly project activities (57\%) and provided the least livelihood and economic benefits.

7. While local forest user groups were a major factor in watershed improvement, collaboration with NGOs and government agencies is important for ongoing technical advice and mediation services. Lower income and caste groups, as well as women, need encouragement to participate in community user groups.

8. A sense of well being and pride in watershed improvements was expressed by many farmers in the watershed, both men and women

9. Water quality in Phewa Lake has deteriorated over the past 30 years with increasing nutrient loading, mainly from municipal sources in Pokhara. Recent road construction contributes significant amounts of sediment to the lake. 
10. Development activities in the watershed began with a top-down emphasis on structural conservation measures, requiring funding from donor agencies. Now activities rely mainly on user groups and collaboration with conservation agencies and NGOs for continuing management.

The impacts of participatory collaboration in watershed management projects are enormous, but often undervalued by both social and economic measures. Community forest user groups now control over about $60 \%$ of the forest land in the Phewa Tal watershed, resulting in increased productivity and sustained yield management. Fodder and fuelwood productivity is nearly twice as great as in formerly government-controlled protection forest. The cost of the community forest program is small compared to the environmental, social, and economic benefits from the change.

\section{References}

Achet, S. and W.M. Fleming. 2006. A watershed management framework for mountain areas: lessons from 25 years of watershed conservation in Nepal. 2006. Journal of Environmental Planning and Management 49(5):1-19 (with S. Achet).

Bhattarai, A.M. and D.R. Khanal. 2005. Communities, forests and law of Nepal: present state and challenges. Federation of Community Forest Users, Nepal, Kathmandu; Pro-public, Kathmandu; and CIEL, Washington DC., 215p.

Brown, S., H. Schreier, P.B. Shah and L.M. Lavakulich. 1999. Modeling of soil nutrient budgets: an assessment of agricultural sustainability in Nepal. Soil Use and Management 15:101-108.

Decore. 1991. Socioeconomic baseline survey of Phewa Tal watershed. Integrated Watershed Management Project, HMG/FINNIDA/FINNEP, 43p.

DSCWM. 1992. Watershed management plan of Phewa Tal watershed. Integrated Watershed Management Project, Technical Paper No. 1/1992, Department of Soil Conservation and Watershed Management - FINNIDA Joint Venture, Kathmandu, Nepal.

FAO 1987. Watershed management and conservation education project, Nepal. Interim Report. FAO, Rome.

Fisheries Research Centre. 2003. Annual report. Nepal Agricultural Research Council, Pokhara, Kaski, Nepal, 124p.

Fleming, W.M. 1983. Phewa Tal catchment management program: benefits and costs of forestry and soil conservation in Nepal. In Forest and 
Watershed Development and Conservation in Asia and the Pacific, L. W. Hamilton, ed., Westview Press, Boulder, p. 217-288.

Gurung, T.B. and R.P. Dhakal. 2003. Seasonal variations of dominant phytoplankton, chlorophyll-a, total phosphorus levels in a shallow basin of Lake Phewa. In 2002/03 Annual Report Agriculture Research Centre (Fisheries), Pokhara, Kaski, Nepal.

Hofer, Thomas. 2003. What are the impacts of deforestation in the Himalayas on flooding in the lowlands? rethinking an old paradigm. In L. Tennyson and P.C. Zingari, eds., Proceedings of the International Conference Water Resources for the Future: Preparing for the Next Generation of Watershed Management Programmes and Projects, Sassari, Sardinia, Italy. Food and Agriculture Organization of the United Nations, Rome, pp. 137-144.

Impat, P. 1981. Hydrometeorology and sediment data for Phewa watershed. Department of Soil Conservation and Watershed Management, HMG/UNDO/FAO, Integrated Watershed Management Project, NEP/74/020, 29p.

Kanel, K.R. 2004. Twenty-five years of community forestry: contribution to millennium development goals. In Kanel, K.R., P. Mathema, B.R.

Kandel, D.R. Niraula, A.R. Sharma and M. Gautam (eds.), Proceedings of the Fourth National Workshop on Community Forestry, Kathmandu, Nepal, pp. 4-18.

Maharjan, M.R. 2004. Payment for environmental services in community forestry. In Kanel, K.R., P. Mathema, B.R. Kandel, D.R. Niraula, A.R. Sharma and M. Gautam (eds.), Proceedings of the Fourth National Workshop on Community Forestry, Kathmandu, Nepal, pp. 371-377.

Mulder, R. 1978. Erosion plot measurements in the Phewa Tal catchment. Phewa Tal Tec. Rpt. No. 6, Integrated Watershed Management/Dept. of Soil and Water Conservation, Kathmandu.

Nakanishi, 1986. Limnological study in Phewa, Begnas and Rupa lakes. In Studies on Distribution, Adaption and Evolution of Microorganisms in Nepal Himalayas ( $2^{\text {nd }}$ Report), JICA, Kathmandu, Nepal.

Nepal Bureau of Statistics. 2001. Nepal census data 2001.

Ojha, H., L. Persha and A. Chhatre. 2009. Community forestry in Nepal: a poliy innivation for local livelihoods and food security. International Forestry Resources and Institutions Program, School of Natural Resources and Environment, University of Michigan, 57p. 
Oli, K.P. 1997. Phewa Lake conservation action plan. National Conservation Strategy Implementation Project commissioned by the National Planning Commission and the World Conservation Union, Kathmandu, Nepal.

Paudel, G.S. and G.B. Thapa. 2001. Changing farmers' land management practices in the hills of Nepal. Environmental Management 28:789-803.

Paudel, G.S. and G.B. Thapa. 2004. Status and management of farmland in the hills of Nepal. Forestry Journal of the Nepal Institute of Forestry 12:125-145.

Poudel, K. 2005. Watershed management in Nepal: challenges and constraints. In M. Achouri, L. Tennyson, K. Upadhyay and R. White, eds. Preparing for the next generation of watershed management programmes and projects. Proceedings of the Asian Workshop, Kathmandu, 11 to 13 September 2003. Watershed Management and Sustainable Mountain Development Working Paper No. 5, Rome, FAO, FORC.

Sthapit, K.M. 2005. Decentralized watershed management: experiences from the soil conservation and watershed management component, Nepal. In M. Achouri, L. Tennyson, K. Upadhyay and R. White, eds. Preparing for the next generation of watershed management programmes and projects. Proceedings of the Asian Workshop, Kathmandu, 11 to 13 September 2003. Watershed Management and Sustainable Mountain Development Working Paper No. 5, Rome, FAO, FORC.

World Bank. 2004. Integrated watershed development project report. World Bank Supervision Mission, October-November, 2004. 